\title{
Effect on Gene Action, Combining Ability and Heterosis for Yield and Yield Attributing Traits in Green Gram (Vigna radiata L. Wilczek)
}

\author{
Manoj Katiyar $^{1 *}$, S.D. Nitesh ${ }^{1}$ and Pradeep Maurya ${ }^{2}$ \\ ${ }^{1}$ Department of Genetics and Plant Breeding, C.S. Azad University of Agriculture and \\ Technology, Kanpur, UP. 208002, India \\ ${ }^{2}$ Legume Section, C.S. Azad University of Agriculture and Technology, Kanpur, \\ UP. 208002, India \\ *Corresponding author
}

\section{A B S T R A C T}

Keywords

Variability, Additive, Nonadditive, GCA, SCA, Heterosis

\section{Article Info}

Accepted:

12 July 2019

Available Online:

10 August 2019
Ten genotypes as lines and three genotypes as testers of mungbean were investigated for combining ability analysis through crosses developed into line $\mathrm{x}$ tester passion. The study revealed that the gene action involved in controlling traits viz., plant height, number of pods per plant, number of seeds per pod and grain yield per plant was non-additive; while the characters viz., number of branches per plant and 100-grain weight had additive gene action. Genotype KM 2264 was found good general combines for most of the yield attributing traits. Among testers KM 2195 was found good general combiner for all the characters. Crosses KM 2312 $\times$ KM 2241, KM $2260 \times$ KM 2241 and KM $2318 \times$ KM 2241 exhibited highly significant positive SCA effects along with higher per se performance for yield contributing traits.

\section{Introduction}

Mungbean [Vigna radiata $(\mathrm{L}$.$) Wilczek] is one$ of the most important legume crops in South and Southeast Asia. It is a warm season annual, highly branches having trifoliate leaves. It is grown under rainfed condition of arid and semi-arid regions of India during kharif and under irrigated condition during summer season. Choice of parents is crucial for breeding high yielding varieties hence the knowledge of combing ability and heterosis assists in selecting the suitable parents for breeding programme and the gene action determines the breeding methodology. Hence, the present investigation was undertaken to assess the gene action involved and the combing ability effects along with heterosis in the mungbean during kharif season.

\section{Materials and Methods}

Ten diverse mungbean genotypes viz., KM 2260, KM 2262, KM 2263, KM 2264, KM 
2310, KM 2312, KM 2318, KM 2319, KM 2356 and KM 2358 were selected as lines and three genotypes KM 2195, KM 2241 and IPM99-125 as testers. These genetically diverse selected genotypes were crossed in line $\times$ tester fashion and thirty hybrids were developed during summer 2017. These hybrids along with their parents were grown in a randomized block design with three replication during kharif 2017. Each hybrid and parent was sown in $3 \mathrm{~m}$ length with $45 \mathrm{x}$ $10 \mathrm{~cm}$ spacing. Recommended cultural practices were followed to grow a good crop. Observations were recorded for days to 50 per cent flowering, plant height $(\mathrm{cm})$, number of branches per plant, number of pods per plant, number of seeds per pod, 100-seed weight $(\mathrm{g})$ and grain yield per plant $(\mathrm{g})$. The data were recorded on five randomly taken plants per entry per replication. The line $\mathrm{x}$ tester analysis was done as per method prescribed by Kempthorne (1957).

\section{Results and Discussion}

Analysis of variance revealed significant differences (Table 1) for all the genotypes for most of character except days to 50 per cent flowering indicating the presence of sufficient amount of variability in expression of traits. The variance of lines and testers along with their interaction was significant for plant height, number of branches per plant, number of pods per plant, number of seeds per pod, 100 -seed weight and grain yield per plant and non-significant for days to 50 per cent flowering indicating the absence of hybrid vigour for this character. Similar results were observed for variances of hybrids and parents vs hybrid. These results are in agreement with earlier findings reported by Saxena and Sharma (1989).

Higher magnitude of variance for hybrids as compared to their parents was observed for plant height, number of branches per plant, 100-seed weight and grain yield per plant indicating the presence of heterosis for these characters. Ratio of SCA to GCA variances was greater than one for characters like plant height, number of pods per plant, number of seeds per pod and grain yield per plant indicating the preponderance of non-additive gene action.

While the traits number of branches per plant and 100-grain weight exhibited SCA to GCA variance ratio less than one indicating the presence of additive gene action. These finding are in agreement with the finding of Manivanna (2002), Singh and Dikshit (2003), Anbumalarmathi et al., (2004), Pandiyan et al., (2006) and Barad et al., (2008).

Genetic mechanism controlling quantitative traits and selection of suitable parents for further hybridization programme were provided through combining ability studies. Making crosses between good combiners and selection of parents on the basis of combining ability are expected to throw out maximum desirable segregants in the upcoming generations.

Days for 50 per cent flowering where negative GCA effect is desirable (Table 2 and Figure 1), the lines-KM 2264 and KM 2319; among tester KM 2195 had significantly higher negative GCA effect in the desired direction. For plant height, the lines KM 2318, KM 2312 and KM 2319; among testers none of them had positive significant GCA effect in the desired direction. Rupal Dhoot et al., (2017) reported significant positive correlation between plant height and seed yield per plant. For number of branches per plant, the line KM 2264 and none of the tester had positive GCA effect. For number of pods per plant the line KM 2264 and tester KM 2195 had significant positive effect. Number of seeds per pod, the lines KM 2264, KM 2262 and KM 2260 and none of testers had positive significant GCA 
effect. 100-seed weight KM 2263, KM 2264, KM 2262, KM 2356, KM 2310 and KM 2260 and among tester KM 2195 had positive significant GCA effect. Lines KM 2264, KM 2356, KM 2260 and KM 2262 and among testers KM 2195 and IPM-99-125 had higher and significant positive GCA effect.
Among the lines KM 2264, KM 2262 and KM 2260 and among the testers KM 2195 were found to have significant GCA effect for most of the character in desired characters. Hence, these genotypes are good combiner and hence can be exploited in the hybridization programme.

Table.1 Analysis of variance, estimates of combining ability variance and degree of dominance for line $\mathrm{x}$ tester mating design of six metric traits in mungbean

\begin{tabular}{|c|c|c|c|c|c|c|c|}
\hline Source of Variation & d.f. & $\begin{array}{l}\text { Plant height } \\
(\mathbf{c m})\end{array}$ & $\begin{array}{c}\text { Number of branches } \\
\text { per plant }\end{array}$ & $\begin{array}{c}\text { Number of } \\
\text { pods per plant }\end{array}$ & $\begin{array}{c}\text { Number of } \\
\text { seeds per pod }\end{array}$ & $\begin{array}{l}\text { 100-gra in } \\
\text { weight }(g)\end{array}$ & $\begin{array}{c}\text { Grain yield } \\
\text { per plant }(\mathrm{g})\end{array}$ \\
\hline Replications & 2 & 1.93 & $0.69 * *$ & 8.91 & 4.28 & 0.56 & 2.41 \\
\hline Genotypes & 42 & $19.14 * *$ & $0.23 * *$ & $69.32 * *$ & $4.32 * *$ & $0.30 * *$ & $12.87 * *$ \\
\hline Parents & 12 & $0.11 * *$ & $0.17 * *$ & $41.26 * *$ & $4.32 * *$ & $0.14 * *$ & $4.83 * *$ \\
\hline Female & 9 & $8.12 * *$ & $0.21 * *$ & $50.88 * *$ & $4.42 * *$ & $0.17 * *$ & $4.85^{* *}$ \\
\hline Males & 2 & $21.94 * *$ & $0.42 * *$ & $29.44 * *$ & $3.33 * *$ & $0.04 *$ & $2.31 * *$ \\
\hline Female vs males & 1 & 1.09 & $0.47 * *$ & 0.87 & $4.43 * *$ & $0.008 *$ & $13.59 * *$ \\
\hline Hybrids & 29 & $14.87 * *$ & $0.38 * *$ & $32.61 * *$ & $3.11 * *$ & $0.17 * *$ & $9.24 * *$ \\
\hline Parent vs hybrid & 1 & $231.20 * *$ & $0.41 * *$ & $587.76 * *$ & $6.85 * *$ & $6.04 * *$ & $231.4 * *$ \\
\hline Error & 84 & 1.61 & 0.12 & 1.50 & 1.11 & 0.5 & 0.78 \\
\hline$\sigma_{g}^{2}$ & & 3.27 & 0.07 & 8.96 & 0.73 & 0.06 & 4.63 \\
\hline$\sigma_{\mathrm{s}}^{2}$ & & 3.99 & 0.5 & 10.32 & 1.09 & 0.05 & 5.11 \\
\hline$\left({ }^{\wedge} \sigma^{2}{ }_{s} / \wedge \sigma_{g}^{2}\right)^{0.5}$ & & 1.08 & 0.81 & 1.06 & 1.18 & 0.89 & 1.17 \\
\hline
\end{tabular}

$*$, ** Significant at $\mathrm{P}=0.05$ and $\mathrm{P}=0.01$, respectively.

Table.2 Estimates of gca effects of parents for six metric traits of a line $\mathrm{x}$ tester mating design in mungbean

\begin{tabular}{|c|c|c|c|c|c|c|c|}
\hline $\begin{array}{l}\text { Source of } \\
\text { Variation }\end{array}$ & $\begin{array}{c}\text { Days to } 50 \\
\text { per cent } \\
\text { flowering }\end{array}$ & $\begin{array}{c}\text { Plant } \\
\text { Height }(\mathbf{c m})\end{array}$ & $\begin{array}{c}\text { Number of } \\
\text { branches per } \\
\text { plant }\end{array}$ & $\begin{array}{c}\text { Number of } \\
\text { pods per } \\
\text { plant }\end{array}$ & $\begin{array}{c}\text { Number of } \\
\text { seeds per pod }\end{array}$ & $\begin{array}{c}\text { 100-seed } \\
\text { weight (g) }\end{array}$ & $\begin{array}{c}\text { Grain yield per } \\
\text { plant (g) }\end{array}$ \\
\hline \multicolumn{8}{|l|}{ Line } \\
\hline KM 2260 & $1.59 * *$ & $-2.46 * *$ & 0.05 & $-1.79 * *$ & $0.42 *$ & $0.06 * *$ & $0.83^{*}$ \\
\hline KM 2262 & -0.38 & 0.15 & -0.05 & $1.52 * *$ & $0.97 * *$ & $0.15 * *$ & $0.23 * *$ \\
\hline KM 2263 & 0.32 & 0.03 & 0.03 & -0.32 & $-0.82 * *$ & $0.21 * *$ & $-0.89 * *$ \\
\hline KM 2264 & $-1.42 * *$ & $-1.73 * *$ & $0.31 * *$ & $1.41 * *$ & $0.72 * *$ & $0.18 * *$ & $0.93 * *$ \\
\hline KM 2310 & $-0.73^{*}$ & $0.59 *$ & 0.08 & 1.58 & -0.24 & $0.08 * *$ & -0.32 \\
\hline KM 2312 & 0.36 & $1.79 * *$ & 0.06 & 0.92 & 0.30 & $-0.19 * *$ & -0.49 \\
\hline KM 2318 & $0.93 * *$ & $2.77 * *$ & -0.19 & 0.31 & -0.37 & $-0.14 * *$ & 0.96 \\
\hline KM 2319 & $-1.02 * *$ & $0.93 * *$ & -0.21 & 1.92 & -0.48 & $-0.20 * *$ & -0.21 \\
\hline KM 2356 & 0.28 & -0.35 & 0.06 & -0.39 & 0.30 & $0.15 * *$ & $0.93 * *$ \\
\hline KM 2358 & 0.19 & 0.14 & $-0.18 *$ & $-4.81 * *$ & $-0.07 * *$ & $-0.15 * *$ & $-1.47 * *$ \\
\hline \multicolumn{8}{|l|}{ Tester } \\
\hline KM 2195 & $-0.39 * *$ & $-0.48 * *$ & 0.08 & $1.41 * *$ & -0.04 & $0.02 * *$ & $0.59 * *$ \\
\hline KM 2241 & 0.21 & 0.29 & $-0.12 *$ & $-0.89 * *$ & -0.04 & $-0.01 *$ & $-0.26 * *$ \\
\hline IPM 99-125 & 0.16 & 0.21 & 0.04 & $-0.52 * *$ & 0.9 & $-0.01 *$ & $0.22 *$ \\
\hline S.E (gi) ${ }_{-}^{+}$ & 0.11 & 0.15 & 0.06 & 0.15 & 0.12 & 0.01 & 0.11 \\
\hline S.E (gj) & 0.30 & 0.33 & 0.10 & 0.32 & 0.26 & 0.02 & 0.24 \\
\hline S.E (gi-gi) $\stackrel{+}{-}$ & 0.28 & 0.32 & 0.09 & 0.31 & 0.27 & 0.01 & 0.23 \\
\hline S.E (gj-gj) ${ }_{-}^{+}$ & 0.52 & 0.59 & 0.16 & 0.33 & 0.49 & 0.03 & 0.42 \\
\hline
\end{tabular}

*, ** Significant at $\mathrm{P}=0.05$ and $\mathrm{P}=0.01$, respectively. 
Table.3 Good specific combiners for grain yield, their performance for some other traits and gca effect of the parents envolved under line $\mathrm{x}$ tester mating design in mungbean

\begin{tabular}{|c|c|c|c|c|c|}
\hline \multirow{2}{*}{$\begin{array}{l}\text { Cross } \\
\text { Grain yield }\end{array}$} & \multirow{2}{*}{$\begin{array}{c}\text { Per se } \\
\text { performance }\end{array}$} & \multirow[t]{2}{*}{ sca effect } & \multicolumn{2}{|c|}{ gca effect } & \multirow{2}{*}{$\begin{array}{c}\text { Traits for which cross also exhibited desirable sca } \\
\text { effects }\end{array}$} \\
\hline & & & $\mathbf{P}_{1}$ & $\mathbf{P}_{2}$ & \\
\hline KM $2312 \times$ KM 2241 & 16.21 & $3.92 * *$ & -0.29 & 0.53 & $\begin{array}{l}\text { number of pods per plant }(5.03 * *) \& 100 \text {-grain weight } \\
\left(0.25^{* *}\right)\end{array}$ \\
\hline KM $2260 \times$ KM 2241 & 15.89 & $2.83 * *$ & -0.85 & 0.62 & $\begin{array}{l}\text { number of grains per pod }(1.93 * *) \& 100 \text {-grain weight } \\
\left(0.16^{* *)}\right.\end{array}$ \\
\hline KM $2243 \times$ KM 2241 & 11.47 & $2.04 * *$ & 0.64 & 0.59 & $\begin{array}{l}\text { number of branches }(0.37 * *) \& 100 \text {-grain weight } \\
(0.07 * *)\end{array}$ \\
\hline KM $2264 \times$ KM 99-125 & 12.31 & $1.92 * *$ & -0.50 & -0.27 & $\begin{array}{l}\text { number of grains per pod }(1.93 * *) \& 100 \text {-grain weight } \\
\left(0.16^{* *)}\right.\end{array}$ \\
\hline KM $2318 \times$ KM 2241 & 8.62 & $1.62 * *$ & -1.47 & 0.15 & $\begin{array}{l}\text { number of branches per plant }\left(0.48^{* *}\right) \& \text { number of } \\
\text { pods per plant }\left(1.48^{* *}\right)\end{array}$ \\
\hline KM $2264 \times$ KM 2195 & 11.35 & $1.39 * *$ & -0.51 & -0.28 & $\begin{array}{l}\text { 100-grain weight }(0.28 * *) \& \text { number of pods per plant } \\
\left(2.89^{*}\right)\end{array}$ \\
\hline KM $2248 \times$ KM 2241 & 12.27 & $0.99 * *$ & 0.93 & 0.49 & number of pods per plant $(1.67 * *)$ \\
\hline KM $2310 \times$ KM 2195 & 11.83 & $0.98 * *$ & 0.21 & -0.28 & $\begin{array}{l}\text { number of branches }(0.37 * *) \& 100 \text {-grain weight } \\
(0.07 * *)\end{array}$ \\
\hline KM $2262 \times$ KM 2241 & 11.21 & $1.02 * *$ & 0.86 & 0.51 & $\begin{array}{l}\text { Number of pods per plant }(3.19 * *) \text {, number of grains per } \\
\text { pod }(1.47 * *), 100 \text {-seed weight }(0.14 * *),) \& \text { number of } \\
\text { branches per plant }\left(0.37^{* *}\right)\end{array}$ \\
\hline KM $2318 \times$ KM 2241 & 13.20 & $0.83 *$ & 0.83 & 0.49 & $\begin{array}{l}\text { number of grains per pod }\left(1.13^{* *}\right), 100 \text {-grain weight } \\
(0.17 * *) \& \text { number of branches per plant }(0.51 * *)\end{array}$ \\
\hline
\end{tabular}

*, ** Significant at $\mathrm{P}=0.05$ and $\mathrm{P}=0.01$, respectively.

Fig.1 Bar graph indicates the gca effects of ten-lines for various agro-morphological characters
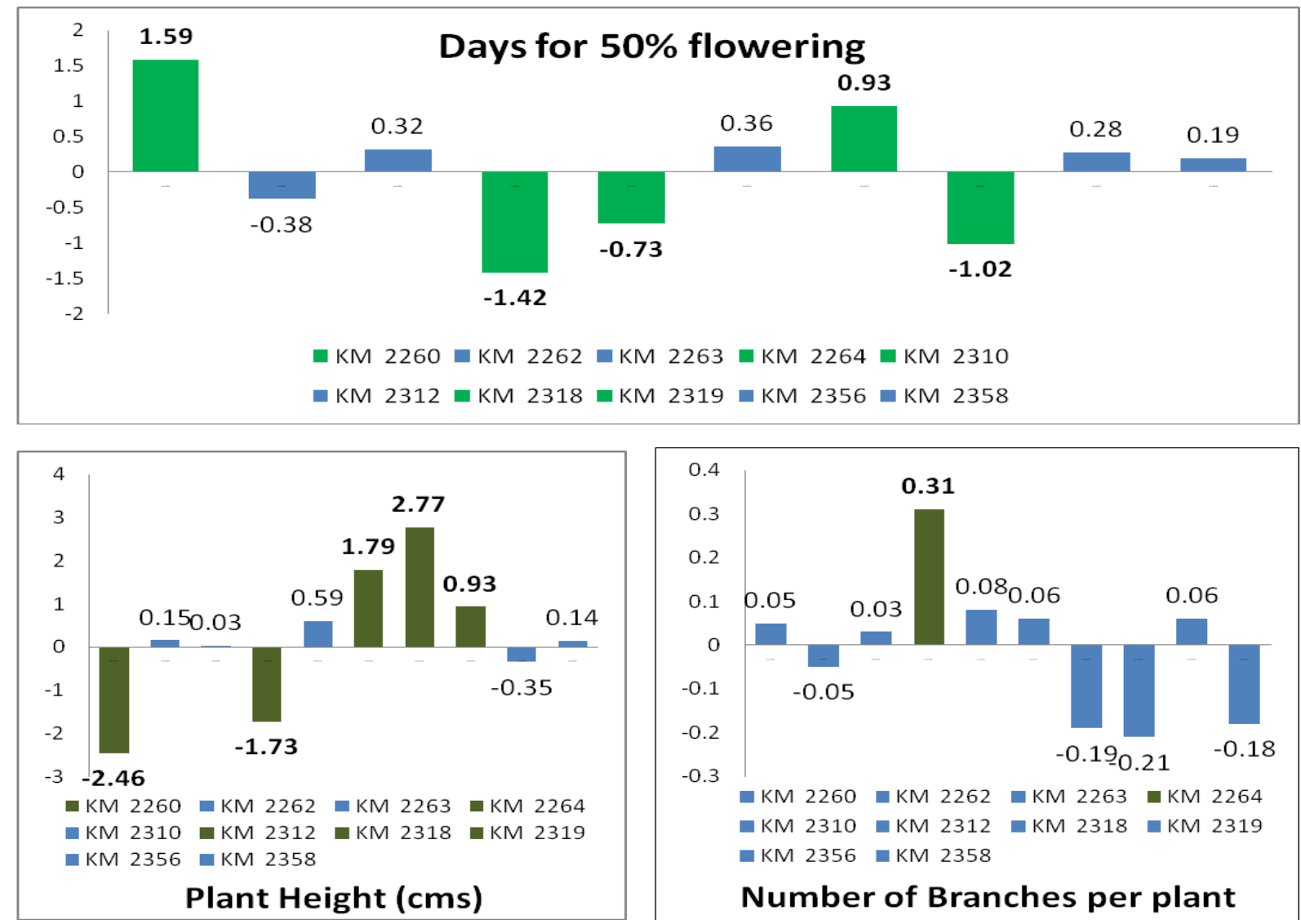

Number of Branches per plant 

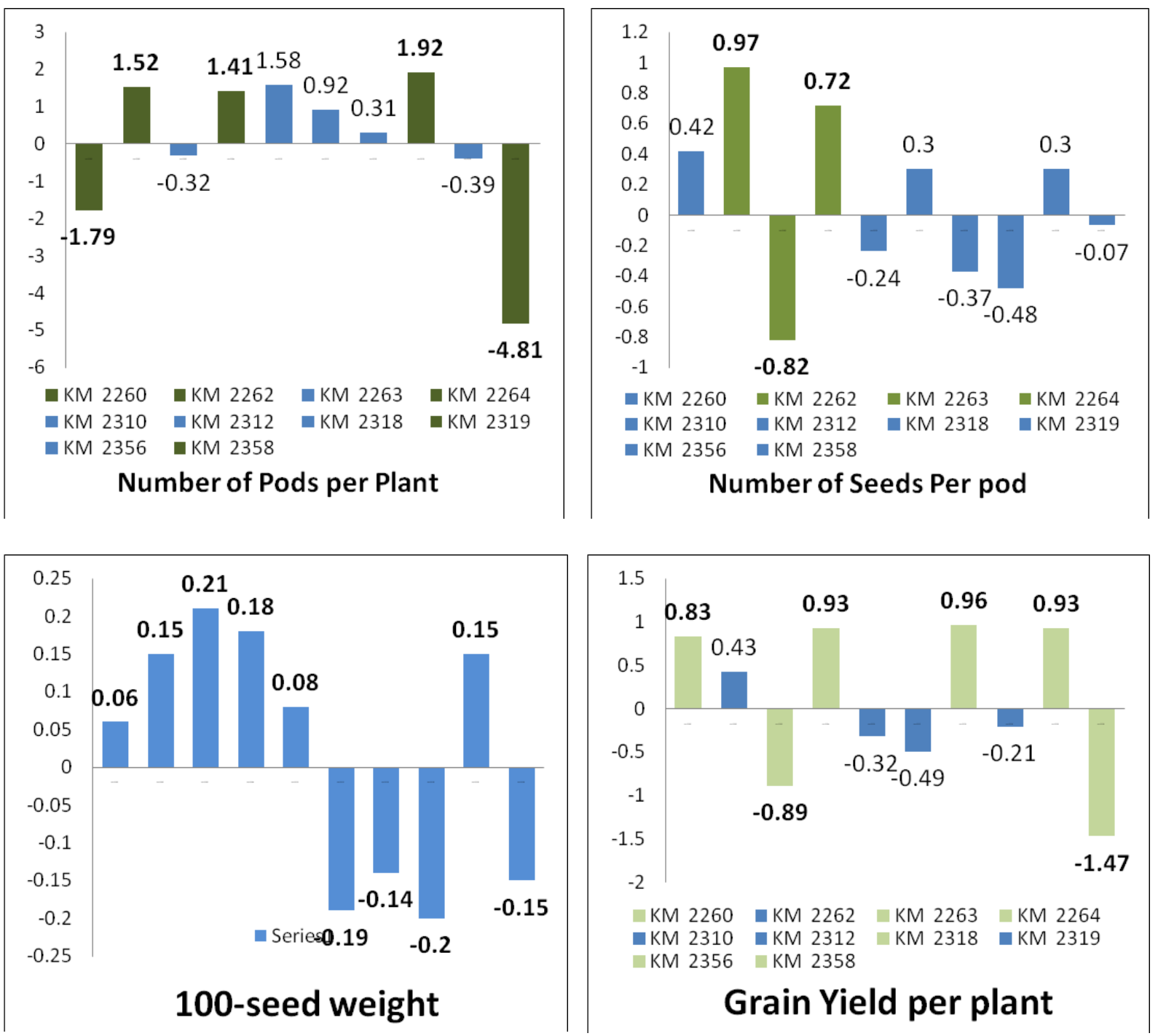

In the present investigation desirable SCA effects for different characters were evaluated to identify potential hybrids (Table 3). The hybrid KM $2312 \times$ KM 2241 has showed highest SCA effect for number of pods per plant and 100-seed weight. The cross KM $2260 \times \mathrm{KM} 2241$ had showed higher SCA effect for number of grains per pod and 100seed weight. KM $2243 \times \mathrm{KM} 2241$ had showed highest SCA effects for the number of branches and 100-seed weight. The hybrid KM $2264 \times$ KM 99-125 exhibited desirable SCA effect for number of grains per pod and 100 -seed weight. The hybrid KM $2318 \times \mathrm{KM}$ 2241 had significant SCA effect for number of branches per plant and number of pods per

plant. Superior SCA effect for traits 100 -seed weight and number of pods per plant was observed for KM $2264 \times$ KM 2195. The cross KM $2248 \times$ KM 2241 had significant SCA effect for only number of pods per plant. The crossing between KM 2310 and KM 2195 had significant SCA effect for number of branches and 100-seed weight. Significant SCA effect in desired direction was observed in hybrid KM $2262 \times$ KM 2241 for number of pods per plant, number of grains per pod, 100-seed weight and number of branches per plant. The lowest significant SCA effect was observed for hybrid KM $2318 \times$ KM 2241 for number of grains per pod, 100-seed weight and number of branches per plant. 
Based on the per se performance (Table 3) the following hybrids arranged in descending order were found to have superior performance: KM 2312 × KM 2241; KM $2260 \times$ KM 2241; KM $2318 \times$ KM 2241; KM $2264 \times \mathrm{KM} 99-125$ and $\mathrm{KM} 2310 \times \mathrm{KM}$ 2195 .

Based on the present investigation carried out in mungbean under Line $\times$ Tester design, the traits plant height, number of branches per plant, 100-seed weight and grain yield per plant showed heterosis. Non-additive gene action was shown for the traits plant height, number of pods per plant, number of seeds per pod and grain yield per plant. Based on the GCA effect the lines KM 2264, KM 2262 and KM 2260 were found to have good combining ability for most of the agronomically important traits, hence can be exploited in further hybridization programme in mungbean improvement. Based on the per se performance and specific combining ability, the hybrid KM $2312 \times \mathrm{KM} 2241$; KM $2260 \times \mathrm{KM} 2241$ and KM $2318 \times \mathrm{KM} 2241$ were found to be superior and hence these hybrids can be utilized in further studies to know the stability of these hybrids in various environmental conditions.

\section{References}

Anbumalarmathi I, Rangasamy P and Babu S. 2004. Studies on combining ability and heterosis for yield and yield components in greengram (Vigna radiata L. Wilczek). Madras
Agricultural Journal 91: 79-82

Barad HR, Pithia MS and Vachhani JH. 2008. Heterosis and Combining ability studies for economic traits in genetically diverse lines of mungbean (Vigna radiata (L.) Wilczek). Legume Research 31(1): 68-71

Kempthorne O. 1957. An Introduction to Genetic Statistics, John Wiley and Sons, Inc., New York. 545pp

Manivannan, L. 2002. Line x Tester analysis in kharif greengram. Legume Research 25:127-130

Pandiyan M, Subbalakshmi B and Jebaraj S. 2006. Combining ability studies in greengram (Vigna radiata L. Wilczek). International Journal of Plant Science $1: 1-5$

Rupal Dhoot, Modha KG, Dhirendra Kumar and Meenakshi Dhoot. 2017. Correlations and Path analysis studies on yield and its components in Mungbean (Vigna radiate (L.) Wilczek). International Journal of Current Microbiology and Applied Sciences 6(5): 370-378

Saxena SD and Sharma RK. 1989. Estimation of combining ability in mungbean (Vigna radiate L. Wilczek). Legume Research 12: 165-169

Singh BB and Dikshit HK. 2003. Combing ability studies for seed yield and architectural traits in mungbean (Vigna radiata L. Wilczek). Indian Journal of Genetics 63:351-352

\section{How to cite this article:}

Manoj Katiyar, S.D. Nitesh and Pradeep Maurya. 2019. Effect on Gene Action, Combining Ability and Heterosis for Yield and Yield Attributing Traits in Green Gram (Vigna radiata L. Wilczek). Int.J.Curr.Microbiol.App.Sci. 8(08): 1461-1466. doi: https://doi.org/10.20546/ijcmas.2019.808.170 